og sætter dem på begreb. Det giver læsningen en særlig intensitet.

Bemarkninger om farverne udkom for første gang i 1977 og på dansk i 1988. Det er godt, at Det lille forlag har taget initiativ til at udsende den igen. Anne-Marie Christensen har til lejligheden skrevet en fin introduktion. Alt $i$ alt en god udgivelse. Hvis man ønsker en indgang til Wittgensteins tænkning og finde ud af, hvorfor han regnes som en af det 20. århundredes mest betydningsfulde filosoffer, er det ikke stedet at starte. Men hvis man gerne vil kildes lidt, inspireres og få en fornemmelse af, hvordan han tænkte, så er det bare at gå i boghandlen og komme i gang med at læse. Som han selv bemærkede: "Man må altid være rede til at lære noget belt nyt."

I filosofien skal man altid spørge: "Hvorledes må man anskue dette problem, for at kunne løse det?” Det er det, som det handler om. Perspektivet, blikket, det der får mønsteret frem. Hvordan man kan bringe en eller anden orden $\mathrm{i}$ begreberne. "Vi står bare der, ligesom oksen foran den nymalede stalddør". Hvad vil det sige? Hvad mente han? Hvor ville han hen med det? Filosoffen er lige så lidt videnskabsmand som oksen. Det falder ingen af dem ind at pille døren ned, slæbe den hen i laboratoriet og foretage en række eksperimenter og undersøgelser. De kan heller ikke finde ud af det. De kan bare stå og glo. Begge håber de på, at der vil ske noget. Nu var Wittgenstein heldigvis ret god til bare at stå og glo. Og så skete der noget. Læs bogen og se selv.

Peter C. Kjargaard

\section{Thomsens stork}

\section{Hans Jorgen Thomsen: Privacy. Forlaget} Modtryk, 235 sider, 229 kr.

Hans Jørgen Thomsens nye bog "Privacy" er ikke nogen let sag, skønt et af dens mål er at argumentere for det private supplements lethed. Fra det private, argumenterer Thomsen, udgår en ødselhed, en righoldig og vital overskridelse, der i metaforisk produktivitet både fastholder det værendes kontingente brudthed og dødelighed - og etablerer en modus vivendi med denne dødelighed i en slags ontologisk metastabilitet. Altså ikke nogen ulidelig lethed, men spekulativt fremreflekteret, ladet op med filosofihistoriens viden om tilværelsens lidelse og udsathed på hjertets bjerge.

For nu at imitere Thomsens metode, der meget består $\mathrm{i}$ im- eller eksplicitte hints til litterære hovedværker og filosofiske grundproblemer. Sådan i al almindelighed, forudsættende at læseren er lige så belæst som Thomsen og har læst på samme måde. Thomsen fremhæver, at hans store forbillede, Jacques Derridas, metode er den dekonstruerende og differerende tekstlæsning - og guderne skal vide, at Derrida er en 
tekstlæser af deres nåde - men peger derved indirekte på, at hans metode er anderledes. Han starter ganske vist sin gennemgang af den moderne privatheds historie med et langt citat fra Kierkegaards dagbøger, som han så vidt jeg kan se får meget filosofisk ud af, men tekstanalytisk ikke udtømmer; også senere rummer hans fremstilling et par store, centrale citater. Men ellers er Thomsen 'overflyveren', der som en rovfugl patruljerer over sit territorium og - metaforisk slår ned, hvor han har lyst. Det virker på undertegnede, der tjener til føden som tekstlæser, både inciterende og provokerende.

For nu straks at demonstrere med et længere citat fra "Privacy": i kapitel 6 gennemgår Thomsen netop metaforens evne til at supplere og afbalancere værens rumlige spredthed gennem en tidslighed, der via Heidegger er analyseret frem som værende 'zum Tode': "[Dette] perspektiv [er] mennesket alene om at kunne sætte i værk med dets potentielle væren til døden. Sætte ind i verden. Hvis det interiøre i den forbindelse kan gøre krav på sit eget ord, kan det passende være ego. Det vil derved straks blive anskueligt, at et sådant ego må defineres som transcendent, cirkulerende ude i verden i eksteriøre fragmenter - øer - af metafysisk mening og ingen andre steder. Cirka således havde Sartre da også allerede defineret ordet i sin pamflet fra trediverne med den sigende titel Egoets transcendens" (p. 129). "Cirka således": jeg kender ikke
Sartres bog og spekulerer på, hvad den siger ud over titlen. Men Thomsens implicitte dialog med Sartre kan producere en metafor om det cirkulerende, meningsproducerende jeg i en i øvrigt uvenlig verden. Det er den metafor, han har brug for. Og den fører så til nye metaforer: "Energien og lidenskaben bag den slags verden stammer fra tidsvilkåret. Og igen er vi ikke som Derrida bange for at pointere sagens eksistentielle og dramatiske natur. Det er endeligheden, der får verdensgrøden til at koge og også ofte til at koge over og brænde på. Sådan at den kan blive nærmest uspiselig for de mennesker, der ikke har anden metafysisk føde til rådighed" (ibid.). Læst i sammenhæng, burde 'verdensgrøden' være en metafor hos Derrida, men det kvier jeg mig ved at tro. Snarere finder Thomsen hos Derrida en licens til at være 'dramatisk' (det er der tidligere argumenteret for) og mener at grødmetaforen her er tilstrækkelig dramatisk. Umiddelbart virker det 'crazy' (for nu at bruge et af de amerikanske begreber, som Thomsen ynder), hvilket kunne hænge sammen med, at Thomsen andre steder bringer privathedens metaforer ind omkring det 'gale' eller 'idiotiske'. Men i den videre sekvens forsøger Thomsen alligevel at fastholde metaforens konsistens og taler nu om, at "[d]et eneste som gælder invariant er, at gryden er i kog, så længe der gøres menneskelige erfaringer"... og at ingen derfor kan "nå udenom den gloende varme i centrum og pe- 
riferi af den menneskelige realitet". Det han ovenfor alligevel antydede, at man kunne, hvis man havde "anden metafysisk føde" til rådighed. Er vi da alle katte, der cirkulerer om den varme grød? Sådan cirka. Kan vi ikke andet, eller burde vi holde op med det? Hvad er egentlig meningen? Derrida ville her sige: sproget har en metaforisk contra-bande, som er magtfuldere end den talende. Eksemplet her kan virke perifert, men det er typisk: Thomsens metode er den billedmæssige, metonymiske bevægelse i teksten, elliptisk kredsende over et reservoir af filosofiske begreber, som han slår ned på efter logikker, der ofte ligger $i$ billederne.

Det er der noget frugtbart i; som eksemplet ovenfor viste, er Thomsens billeder ikke alene komplekse og derfor også ofte forvirrende, men også morsomme og plastiske. Thomsen om-taler sin filosofihistorie fra Kirkegaard over Husserl, Heidegger, Sartre, Levinas til Rorty og Derrida i en stadig billedproduktion med litteratur som en diskret samtalepartner, som han til slut undskylder ikke at havet viet eksplicit opmærksomhed. Måske kan de egentlige metaforproducenter, digterne, noget, som vi filosoffer ikke kan, antyder han til sidst i sin bog. "Prousts værk kunne f.eks. være blevet læst med interesse for, hvilken rolle hemmelighed og hemmeligholdelse spiller i det" (p. 192). Unægtelig: den højmodernisme, Thomsen gang på gang alluderer til, har nemlig henfaldetheden til en meningstømt verden som sit hovedtema, dødens og brudthedens uafvendelighed, men også sprogets evne til på disse ruiner at rejse sin bygning, som T.S. Eliot formulerer det i det digt "The Waste Land", som Thomsen har en spændende reference til. Når de moderne forfattere bevæger sig hulter til bulter i den kontingente verden, dukker der ofte et smukt billede op af bevægelserne. Som i den afrikanske legende om at tegne en stork, som Karen Blixen bruger i "Den afrikanske farm", og som Thomsen - igen uden eksplicit reference, endsige citater - inddrager som en slags formmatrice for sin egen tekst. Ud af kaos fødes kunstens dansende stjerne, for nu at citere den Nietzsche, der med sin radikale besindelse på verdens endelighed og den enkelte ret til sprogligt at definere sig selv, er en af de vigtige forløbere for den filosofiske tradition (Heidegger, Derrida, Rorty), Thomsen tager afsæt i.

Når jeg alligevel ikke tror, at et udfoldet kapitel om romankunsten ville have tilføjet så meget til Thomsens projekt, skyldes det ikke alene at Thomsen er bedre som tekstproducent end som tekstlæser. Men også at der for enden af hans bevægelse gennem metaforhuset står en billedløshed, der er hinsides al (sund) fornuft: Gud, der nok ét sted kaldes en metafor (p. 181), men et andet beskrives som "billedløs og uanskuelig" (p. 166), en tredje instans, der er til stede i metaforhuset som "en addition i det 
interiøre af erfaringer af det første - naturen - og det andet, de andre i mitsein" (ibid.). Jeg læser hele "Privacys"s filosofiske bue som et forsvar for denne nye metafysiske instans midt $\mathrm{i}$ accepten af det 20 . århundredes opgør med metafysikken, en ny onto-teologi, der bebor den kontingente verden med en let, munter og ødsel, men i sidste instans billedløs tro. En tro, der ud over at trøste den tørstende sjæl, skal supplere den liberale kapitalistiske økonomi, som har vist sig at være den eneste, der kan udtrykke den moderne frihedslængsel og forsyne os verdensborgere med (fysisk) føde. Supplere denne økonomi, som Thomsen vedholdende, men ikke særligt konkret bekender sin tro på, med holistisk åndelighed og - ja - metafysisk trøst.

Jeg går ud fra, at Hans Jørgen Thomsen og jeg kan blive enige om, at denne tro ser meget anderledes ud end den præsident Bush i disse dage så hyppigt bekender sig til. Også at den liberale økonomi, der er menneskets eneste mulige måde at have sin fysiske udveksling med verden på, ser noget anderledes ud end det imperialistiske verdensherredømme, samme Bush er i færd med at påtvinge den øvrige verden. Men hvordan ser den så ud? Hvis man ikke kan danne sig billeder af Gud, kan man så heller ikke konkret beskrive det ønskede Guds rige? Jeg føler mig som filosofisk lægmand (sådan nogle som Kierkegaard, i følge Thomsen, følte sig inderligt forbundne med) overbevist af Thomsens gennemgang af det moderne opgør med transcendentalismen og den logocentristiske ontologi. Jeg synes det er stærkt gjort. Jeg synes også at begrebet privacy som erstatning for en lang række traditionelle begreber for det individuelle og indre, afskåret fra værensfylden, men sprogligt arbejdende for at overvinde kløften, er godt. Det slår mig ikke som oplagt, men provokerer i sin kantethed og uortodokse andethed. Det gør sprogligt, hvad det hævder at betegne. Så langt og så godt er jeg ført gennem ørkenen, frem til udsigten til det hellige land. Men her rammes jeg af billeforbudet: der er intet at se, "Öd' und leer das Meer", som Eliot i "The Waste Land" citerer fra Wagners "Tristan und Isolde". Men hvor Thomsen slutter sin bog med en lidt halvhjertet bekendelse til den moderne roman og en "uvidenskabelig efterskrift", der kompetent, men noget efterhængt diskuterer forholdet mellem naturvidenskab og humanvidenskab, arbejder Eliot sig igennem den moderne "heap of broken images" frem til en ny billedlighed og "the awful daring of a moment's surrender/which an age of prudence can never retract". Er det denne hengivelse, denne kasten sig ud på 70.000 favne vand, som Thomsen ikke vover - bange for at blive opslugt af "the death by water"?

Det kan jeg naturligvis ikke vide, men jeg kan - med Kierkegaard vel - spørge, om man kan filosofere sig (spekulere om man vil) frem til 
troen. Et spørgsmål, jeg som så mange andre spørgsmål efter læsningen af denne righoldige bog lades tilbage med.

Steen Klitgard Povlsen

\section{Europæisk idehistorie} Hans-Jorgen Schan₹: Europaisk idebistorie. Historie, samfund, eksistens, Host og son 2002, 237 sider, 350 kr.

To professorer ved Aarhus Universitet udgav i det forgangne århundrede hver sin vældig gode oversigt over filosofiens historie, Justus Hartnacks Filosofiske problemer (1956) og Johannes Sløks De europaiske ideers historie (1963); den første beregnet som lærebog ved filosofikum, en disciplin alle universitetsstuderende dengang skulle til eksamen i, den anden for gymnasiet, hvorfor gymnasierektor Erik Lund og fysiklærer Mogens Pihl stod som medforfattere, skønt Sløk havde skrevet næsten det hele. Ingen af disse to bøger ville være filosofihistorier i traditionel forstand. Hartnack ville slet ikke skrive historie. For ham havde filosofi og historie intet med hinanden at gøre. Hans bog var, som titlen angiver, en bog om de vigtigste filosofiske problemer, som er blevet "opdaget" og diskuteret $\mathrm{i}$ historiens løb. Han tog dem op i kronologisk rækkefølge, men kunne ifølge sit eget program udmærket have behandlet dem i en anden, mere systematisk rækkefølge, og den historiske kontekst, de opstod $i$, interesserede ham ikke. Hvad der interesserede ham, var problemerne og forsøgene på at løse dem. Var der tale om pseudoproblemer, som skyldtes sprogligt eller filosofisk roderi, eller æate filosofiske problemer, som stadig kalder på løsningsforsøg. Bogen var, kan man sige, en kronologisk ordnet eksempelsamling, hvor studenterne kunne stifte bekendtskab med forskellige måder at formulere filosofiske problemer og argumentere for deres løsning på. Sløks bog derimod ville gerne være en historie, men en idehistorie, ikke en filosofihistorie. Formålet var tilsyneladende ikke at gennemgå kongerækken af filosoffer og deres forfatterskaber, men at præsentere de vigtigste ideer, som i historiens løb er dukket op i Europa, ikke kun inden for filosofien, men inden for teologi, kunst, politik m.v. Overskrifterne angiver disse ideer og nævner ingen filosofnavne. Ud over Platon figurerer der ikke et eneste navn i Sløks overskrifter og indholdsfortegnelse.

Schanz tegnede for nogle år siden i essaysamlingen Det historiske (1996) et rids af filosofihistoriernes historie. Han skelnede mellem, hvad han kaldte den "ortodokse" eller traditionelle filosofihistorie, som udvikledes i det 19. århundrede, og to nye tilgange, som opstod i opposition hertil i årene omkring 1900: en analytisk og en "geistesgeschichtlich". Den første - eksemplificeret med Bertrand Rus- 